\title{
Comparison of smoltification in Atlantic salmon (Salmo salar) from anadromous and landlocked populations under common garden conditions
}

\author{
Jorma Piironen ${ }^{1, *}$, Päivi Kiiskinen², Hannu Huuskonen², \\ Marjo Heikura-Ovaskainen² \& Matti Vornanen² \\ 1) Finnish Game and Fisheries Research Institute, Yliopistokatu 6, Fl-80100 Joensuu, Finland \\ (*corresponding author's e-mail: jorma.piironen@rktl.fi) \\ 2) University of Eastern Finland, Department of Biology, P.O. Box 111, Fl-80101 Joensuu, Finland
}

Received 17 Feb. 2012, final version received 31 July 2012, accepted 21 Aug. 2012

Piironen, J., Kiiskinen, P., Huuskonen, H., Heikura-Ovaskainen, M. \& Vornanen, M. 2013: Comparison of smoltification in Atlantic salmon (Salmo salar) from anadromous and landlocked populations under common garden conditions. - Ann. Zool. Fennici 50: 1-15.

We compared smolt physiology of Atlantic salmon stocks, that migrate from freshwater stream environments to a freshwater lake (Lake Saimaa, Finland), from the Neva River (Russia) to the brackish water of the Baltic Sea, and from the Teno River (Finland/ Norway) to the full-strength seawater of the Arctic Ocean. The three fish stocks were reared under common garden conditions, and ion homeostasis, seawater tolerance, activities of gill and kidney $\mathrm{Na}, \mathrm{K}-\mathrm{ATP}$ ase and $\left[{ }^{3} \mathrm{H}\right]$ ouabain binding of gill and kidney tissues were determined at different phases of smoltification. Activity of gill $\mathrm{Na}, \mathrm{K}$ ATPase and number of gill $\left[{ }^{3} \mathrm{H}\right]$ ouabain binding sites reached peak values in May and were strongly suppressed in July. Osmolality and $\mathrm{Na}^{+}, \mathrm{Cl}^{-}$, and $\mathrm{Mg}^{2+}$ ion concentrations of blood plasma decreased during smoltification. $\alpha 1 \mathrm{a}$ and $\alpha 1 \mathrm{~b}$ isoforms of gill $\mathrm{Na}, \mathrm{K}-$ ATPase decreased and increased, respectively, during smoltification. Although small differences appeared at some points in time, the seasonal pattern and magnitude of changes in smolt characteristics were generally similar in the Saimaa salmon and in the anadromous stocks of the Neva and Teno salmon. It is suggested that the strong smoltification process of the landlocked Saimaa salmon is somehow necessary for migration of the young salmon from river to lake and therefore has been retained in evolution.

\section{Introduction}

Salmonid fish are renowned for their migration between freshwater and seawater habitats: they are born in a freshwater river and after 2-7 years of development migrate to the sea for rapid growth and sexual maturation in the nutrient-rich habitat (Thorpe 1994). The habitat shift is associated with a critical developmental process called smoltification or the parr-smolt transformation which involves profound changes in physiology of the fish, in particular conversion from hyperosmotic to hypoosmotic ion regulation and increase in seawater tolerance (Hoar 1976, Folmar \& Dickhoff 1980, McCormick \& Saunders 1987). Environmental cues, espe- 
cially photoperiod and temperature, initiate the smoltification process which is mediated and promoted by several hormones including growth hormone, cortisol, thyroid hormones and insulinlike growth factor 1 (Björnsson et al. 2011).

The transformation of the gills, the main ion regulatory organ of the fish, from a saltabsorbing to a salt-secreting tissue is an essential part of smoltification. Remodeling of the gill ion regulation is based on profound changes in expression and function of several ion-transport molecules, in particular the Na,K-ATPase (Saunders \& Henderson 1978, Boeuf et al. 1985, Sullivan et al. 1996, Seidelin et al. 2001, Evans et al. 2005, Nilsen et al. 2007, Madsen et al. 2009). $\mathrm{Na}, \mathrm{K}$-ATPase is the power supply for osmotic and ionic regulation in both freshwater- and seawater-acclimated salmon by providing electrochemical force for vectorial transport of $\mathrm{Na}^{+}$ and $\mathrm{Cl}^{-}$across the gill epithelium. It occurs as a heterodimer of $\alpha$ and $\beta$ subunits, both of which are represented by several gene products in fish (Rajarao et al. 2001, Blasiole et al. 2002, Gharbi et al.2005). Tissue-specific differences in $\alpha$ - and $\beta$-subunit composition of the Na-pump suggest that $\mathrm{Na}, \mathrm{K}$-ATPase isoenzymes are functionally different (Blanco \& Mercer 1998, Rajarao et al. 2001, Canfield et al. 2002, Gharbi et al. 2005). Specialization of function seems to apply also to the Na,K-ATPase isoforms of the salmon gills. An isoform shift from $\alpha 1$ a to $\alpha 1 \mathrm{~b}$ occurs during the parr-smolt transformation, when the salinity tolerance of juveniles increases (Richards et al. 2003, Bystriansky et al. 2006, Nilsen et al. 2007, Madsen et al. 2009, McCormick et al. 2009), suggesting that the $\alpha 1 \mathrm{a}$ isoform is involved in $\mathrm{Na}^{+}$uptake in freshwater, while the $\alpha 1 \mathrm{~b}$ isoform is responsible for $\mathrm{Na}^{+}$secretion into the hyperosmotic seawater. Indeed, certain differences in the primary structure of different $\mathrm{Na}, \mathrm{K}$-ATPase $\alpha$-subunits represent adaptations for $\mathrm{Na}^{+}$uptake and $\mathrm{Na}^{+}$excretion, respectively (Colina et al. 2007). Seasonal up-regulation of the gill Na,KATPase activity is regarded as a prerequisite for hypoosmotic regulation and seawater tolerance of the salmon smolt (Borgatti et al. 1992).

Among the numerous Atlantic salmon (Salmo salar) populations there are several landlocked stocks which do not migrate into the sea but complete their whole life-cycle in freshwa- ter (MacCrimmon \& Gots 1979, Berg 1985). Some of these landlocked populations are still migratory, but now migrate between riverine and lacustrine habitats without experiencing any salinity change. Even though not exposed to seawater, the nonanadromous salmon go through a similar smoltification process as the anadromous salmon. However, there seems to be differences in the extent of the parr-smolt transformation between various non-anadromous salmon stocks (Barbour \& Garside 1983, Chernitsky \& Loenko 1983, Koch 1983, Berg 1985, McDowall 1988, Birt et al. 1991, Staurnes et al. 1992, Birt \& Green 1993, Schmitz 1995, Kiiskinen et al. 2002, Nilsen et al. 2003) which may be associated with differences in migration behaviour of the populations (Barbour \& Garside 1983). Salmon which migrate between two freshwater habitats may have retained stronger smoltification process, perhaps as an indispensable part of migration from a meagre growing habitat of the river into a more favourable environment of the downstream lake. In contrast, the landlocked populations which do not have access to favourable growing habitats due to geographical barriers (or if the available habitats do not significantly differ in regard to food availability), may have lost some of the smolt characteristics due to negative selection pressure (Schmitz 1995). Indeed, a genome-wide microarray analysis of the gill transcripts between some anadromous and nonanadromous Atlantic salmon populations suggest that at the genetic level smoltification process can be fairly similar in sea-run and landlocked populations (Vornanen et al. 2009, Lemmetyinen et al. 2013).

Although a genome-wide survey of gene transcripts provides a much broader view to smoltification process than determination of a predetermined selection of gene transcripts, enzyme activities or hormone levels (Björnsson \& Bradley 2007), it does not directly assess physiological status of the smolting fish. The objective of the present study is to compare physiology of smolting fish from three Atlantic salmon stocks that migrate from freshwater streams to a freshwater lake (the Lake Saimaa, Finland), from the Neva River (Russia) to the brackish water of the Baltic Sea, and from the Teno River (Finland/Norway) to the full-strength 
seawater of the Arctic Ocean. These three fish stocks were reared under common conditions in freshwater to see whether ion homeostasis, seawater tolerance and activity of the $\mathrm{Na}, \mathrm{K}$-ATPase differ between salmon stocks depending on the destination of smolt migration.

\section{Material and methods}

\section{Animal origin and care}

For experiments, we used three Atlantic salmon (Salmo salar) stocks that differ in regard to their geographical origin and growth habitat: a landlocked nonanadromous lake-run and freshwateradapted Saimaa salmon (LS, landlocked stock), an anadromous sea-run and brackish-water-adapted Neva salmon (BS, brackish water stock), and an anadromous sea-run and seawater-adapted Teno salmon (SS, seawater stock). LS lives in Lake Saimaa in eastern Finland $\left(62^{\circ} \mathrm{N}\right)$ and spawns in upstream rivers. BS spawns in the Neva River in Russia $\left(60^{\circ} \mathrm{N}\right)$ and migrates to the Baltic Sea for growth. SS reproduces in the Teno River, a northern border river between Finland and Norway $\left(70^{\circ} \mathrm{N}\right)$, and migrates to the Arctic Ocean. The three stocks are genetically different. The Neva and Teno salmon are genetically closer to each other (a fraction of total genetic variation due to population differences $F_{\mathrm{ST}}=0.114$ ) than to the Saimaa salmon $\left(F_{\mathrm{ST}}=0.286\right.$ and 0.306 for Neva/ Saimaa and Teno/Saimaa, respectively) (Tonteri et al. 2005). Saimaa salmon has been land-locked since the last ice age for ca. 8000-10000 years.

The fish were reared under common garden environment at the Saimaa Fisheries Research and Aquaculture Station in Enonkoski, Finland. Eggs and milt of the Saimaa and Neva salmon were obtained from the brood fish of the Saimaa hatchery, while those of the Teno salmon were taken from the brood stock of the Inari Fisheries and Aquaculture Station (Finland) and transported to Enonkoski. In order to produce progeny representative for each stock, fertilizations were done (in 2005) using the first hatchery-generation males and females from two (BS) or three (LS, SS) different year classes. Females and males from different year classes were crossed to prevent inbreeding. A total of 30 females and 30 males from LS and SS, and 45 females and 45 males from BS were used for fish reproduction.

The fish were maintained from the fertilization of eggs onwards in freshwater under the same experimental conditions (a common garden culture) to ensure that the differences appearing in physiology during development are inherent to different stocks and not due to variation in environmental conditions. All fertilizations were done on the same day to ensure similar environmental conditions for all salmon stocks from the very beginning. The eggs from each stock were incubated in indoor hatchery troughs. After hatching, the fry of each stock was grown in separate troughs in the same hall for the duration of the study. The fish of each stock were divided into three replicate tanks (200 fish/ tank; $2.1 \mathrm{~m}^{2}$, ca. 420 l) from which the fish were randomly sampled (6 fishes/tank i.e. 18 fishes/ population at each time) for analyses. Since the growth season at northern latitudes is relatively short, the development of the 4-week-old embryos was accelerated by gradually elevating water temperature from 4 to $10{ }^{\circ} \mathrm{C}$ during a few weeks. The fish were maintained at this temperature until the ambient water temperature reached $10{ }^{\circ} \mathrm{C}$. Thereafter, a simulated natural photoperiod $\left(62^{\circ} \mathrm{N}\right)$ and natural ambient water temperature (Fig. 1) were used to allow these environmental cues to entrain the development of the fish. The fish were fed ad libitum nutrient pellets (naturaG EWOS, Florø, Norway). All experiments were conducted with permission of the ethical committee of the Game and Fisheries and Research Institute (permission 18/05).

\section{Description of smoltification process}

We followed strength and timing of smoltification of two-year-old fish in January, April, May and July by:

- measuring seasonal changes in the activity of gill and kidney $\mathrm{Na}, \mathrm{K}$-ATPase,

- determining the number of gill and kidney Na-pumps by $\left[{ }^{3} \mathrm{H}\right]$ ouabain binding,

- examining gill transcript abundances (pooled samples) of $\alpha 1 \mathrm{a}$ and $\alpha 1 \mathrm{~b}$ isoforms of the $\mathrm{Na}, \mathrm{K}-\mathrm{ATPase}$, 


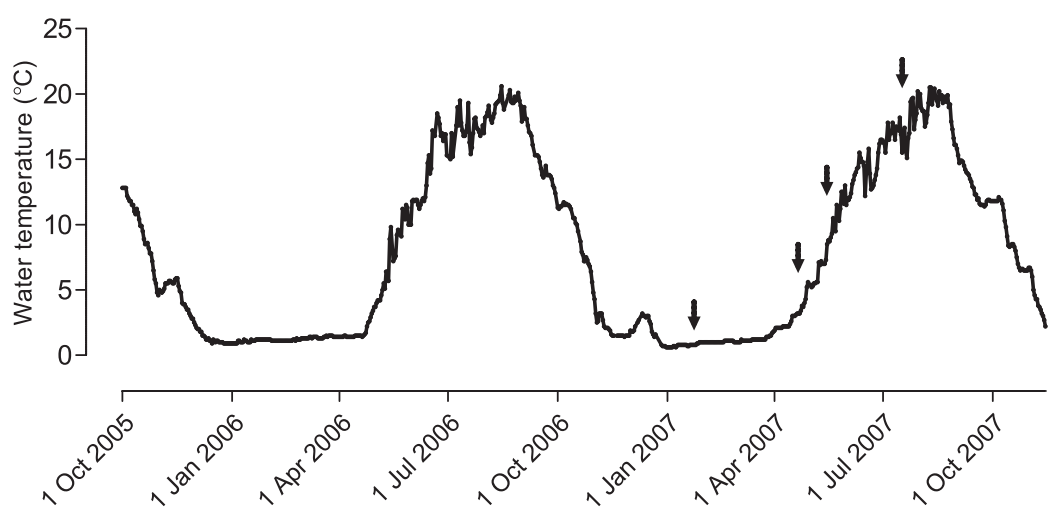

Fig. 1. Water temperature in the indoor tanks of the Enonkoski fish hatchery during the study giving the whole thermal history of the fish. Sampling dates are indicated with arrows.
- ion $\left(\mathrm{Na}^{+}, \mathrm{K}^{+}, \mathrm{Mg}^{2+}\right.$ and $\left.\mathrm{Cl}^{-}\right)$and osmolality analyses of blood plasma, and

- determining muscle water content.

All the fish were fasted for two days before sampling. External morphological characteristics of smoltification including condition factor and silvering of the skin were also recorded. The fish (18 individuals from each population) were stunned by a blow to the head and killed by cervical dislocation. The fourth gill arch was excised from the left side of the gill. Approximately 1.5-2-cm-long piece of the anterior part of a kidney was dissected for analyses. All tissue samples including blood plasma samples were snapfrozen in liquid nitrogen for storage at $-80{ }^{\circ} \mathrm{C}$ until used for analyses.

\section{Seawater challenge tests}

We exposed 14-19 randomly selected fish from each salmon stock to a seawater challenge test (SW test) for 48 hours at salinity ca. 30\%o (range 29\%o-33\%o); seawater was prepared using ionbalanced salt (Instant Ocean) (Blackburn et al. 1987). The volume of the test basin was 3201 , and the water was continuously oxygenated by aquarium aerators. The fish were accustomed to test conditions for two days prior to adding the salt and were not fed during the acclimation or the exposure. The tests were conducted in January, May and July at ambient water temperature (Fig. 1). Water salinity was determined gravimetrically after the 48-h exposure. The same parameters as for smolting fish (plasma osmo- lality, ion concentrations, Na,K-ATPase activity, $\left[{ }^{3} \mathrm{H}\right]$ ouabain binding) were used to assess the osmoregulatory capacity of the test fish. The change in muscle water during seawater exposure is expressed as a difference in muscle water content between fish in freshwater and fish exposed to seawater.

\section{Determination of plasma constituents}

Plasma concentrations of $\mathrm{Na}^{+}, \mathrm{K}^{+}$and $\mathrm{Cl}^{-}$were determined using ion selective electrodes. Plasma $\mathrm{Mg}^{2+}$ was measured colorimetrically using a complexometric indicator "calmagite" according to the method of Gindler and Heth (1971). Plasma osmolality was determined as freezing point depression (Type 6 Osmometer, Axel Löser Messtechnik, Berlin). Concentrations of glucose and triglycerides in the blood plasma were measured following the methods of Trinder (1969) and Wahleweld (1974), respectively, using Konelab 30i Clinical Chemistry Analyzer (ThermoFisher Scientific, Vantaa, Finland).

\section{$\mathrm{Na}, \mathrm{K}-\mathrm{ATPase}$ activity}

We determined Na,K-ATPase activities of gill and kidney from the release of inorganic phosphate (Atkinson et al. 1973). Approximately 1.5-2-cmlong piece of the anterior part of a kidney and soft parts of the gill tissue, scraped free from the cartilage of the gill arches, were used for the analyses. Tissue samples were homogenized in 15 volumes of buffer containing (mmol $\left.\mathrm{l}^{-1}\right)$ : 250 sucrose, 
$2 \mathrm{Na}_{2}$ EDTA, 0.005 phenylmethylsulfonyl fluoride, 25 Tris- $\mathrm{HCl}$ at $\mathrm{pH} 7.5$. $\mathrm{Na}, \mathrm{K}-\mathrm{ATPase}$ activity was obtained as the difference in inorganic phosphate liberatation in the presence and absence of $3 \mathrm{mM}$ ouabain in a test volume of $1.0 \mathrm{ml}$ of the ATPase medium containing ( $\mathrm{mmol} \mathrm{l}^{-1}$ ): $5 \mathrm{Na}_{2}$ ATP, $5 \mathrm{MgCl}_{2}, 20 \mathrm{KCl}, 100 \mathrm{NaCl}, 50$ Tris-HCl, 1 EGTA and $5 \mathrm{NaN}_{3}$ at $\mathrm{pH}$ 7.2. After 10 min preincubation of the sample in the medium, the reaction was started with the addition of $25 \mu 1$ of $100 \mathrm{mM}$ ATP stock solution, and the incubation was continued for $60 \mathrm{~min}$ at $25^{\circ} \mathrm{C}$. Under these assay conditions, the release of inorganic phosphate was linear with time up to the end point of the incubation. Activity of the background ATPase was obtained as ouabain-resistant ATPase activity corrected with the time-dependent breakdown of ATP in the absence of homogenate. Na,K-ATPase activities are given as $\mu$ moles of inorganic phosphate liberated per $\mathrm{g}$ tissue wet weight in one minute $(\mu \mathrm{mol}$ $\left.\mathrm{P}_{\text {inorg }} \mathrm{g}^{-1} \mathrm{~min}^{-1}\right)$.

\section{$\left[{ }^{3} \mathrm{H}\right]$ ouabain binding}

Ouabain binds specifically to the $\alpha$-subunit of the Na,K-ATPase with one-to-one stochiometry and therefore $\left[{ }^{3} \mathrm{H}\right]$ ouabain binding can be used as a measure for the number of sodium pump units. $\left[{ }^{3} \mathrm{H}\right]$ ouabain (Amersham, Little Chalfont, UK) binding was performed in a total volume of $0.5 \mathrm{ml}$ of solution containing $0.5 \mathrm{mg}$ of wet tissue and $4 \mathrm{nM}\left[{ }^{3} \mathrm{H}\right]$ ouabain. The binding buffer included $\left(\mathrm{mmol} \mathrm{l}^{-1}\right)$ : $4 \mathrm{H}_{3} \mathrm{PO}_{4}, 4 \mathrm{MgCl}_{2}$ and 50 Tris- $\mathrm{HCl}$ at $\mathrm{pH} 7.4$ (Vornanen \& Paajanen 2006). The reaction was terminated with $6 \mathrm{ml}$ of ice-cold wash buffer containing ( $\left.\mathrm{mmol} \mathrm{l}^{-1}\right)$ : 4 $\mathrm{MgCl}_{2}, 50$ Tris- $\mathrm{HCl}$ at $\mathrm{pH} 7.4$ at $20{ }^{\circ} \mathrm{C}$, and the suspensions were immediately filtered through Whatman GF/B filters (Merck, Poole, UK) with three 6-ml washes of cold buffer. Filters were soaked in $10 \mathrm{ml}$ of scintillant (Ready Protein+, Beckman), and $\left[{ }^{3} \mathrm{H}\right]$ ouabain bound to the filter was quantified by liquid scintillation counting (Wallac 1414 WinSpectral, Wallac, Finland). Nonspecific binding was determined by measuring $\left[{ }^{3} \mathrm{H}\right]$ ouabain binding in the presence of $100 \mu \mathrm{M}$ unlabeled ouabain (Sigma, Poole, UK). Binding experiments were conducted at $20{ }^{\circ} \mathrm{C}$.

\section{Real time quantitative PCR}

We extracted total RNA from the soft gill tissue which was pooled from four fish for each sample. The total number of RNA preparations was 12 (3 stocks $\times 4$ time points). Samples were DNase treated and used in the first-strand cDNA synthesis, as previously described (Hassinen et al. 2007). For qPCR, contaminating DNA was removed using RQ1 RNase-Free DNase (Promega, Madison, WI) and the absence of contamination was verified for each sample by a control run containing all other reaction components except the reverse transcriptase. Firststrand cDNA was synthesized and quantitative PCR was performed using DyNAmo ${ }^{\text {TM }}$ SYBR $^{\circledR}$ Green 2-Step qRT-PCR Kit (Finnzymes, Espoo, Finland) and DNA Engine ${ }^{\circledR}$ thermal cycler supplied with Chromo4 Continuous Fluorescence Detector (MJ Research, Waltham, MA) (Table 1). Reaction conditions were as follows: $94{ }^{\circ} \mathrm{C}$ for $15 \mathrm{~min}, 40$ cycles of $94{ }^{\circ} \mathrm{C}$ for $10 \mathrm{~s}$, $57{ }^{\circ} \mathrm{C}$ for $20 \mathrm{~s}$, and $72{ }^{\circ} \mathrm{C}$ for $30 \mathrm{~s}$. After PCR, the amplification of specific products was monitored by melting curve analysis. All analyses were run in 5 technical replicates. DnaJA2 (DnaJ subfamily A member 2) and elongation factor 1a were initially used as reference genes (Vornanen et al. 2005, Hassinen et al. 2007). As preliminary analyses indicated that both reference genes gave practically identical results, the EF1a was

Table 1. Primers used in the real time quantitative PCR.

\begin{tabular}{lll}
\hline Gene & Forward primer & Reverse primer \\
\hline Na, K-ATPase $\alpha 1 \mathrm{a}$ & GGCCGGCGAGTCCAAT & GAGCAGCTGTCCAGGATCCT \\
$\mathrm{Na}$, K-ATPase $\alpha 1 \mathrm{~b}$ & CTGCTACATCTCAACCAACAACATT & CACCATCACAGTGTTCATTGGAT \\
DnaJ2 & TGGGCCGCTCTCTTGTATGT & TTGTAAGGAGAAGTGAGG \\
Elongation factor 1a & GAGACCCATTGAAAAGTTCGAGAA & GCACCCAGGCATACTTGAAAG \\
\hline
\end{tabular}



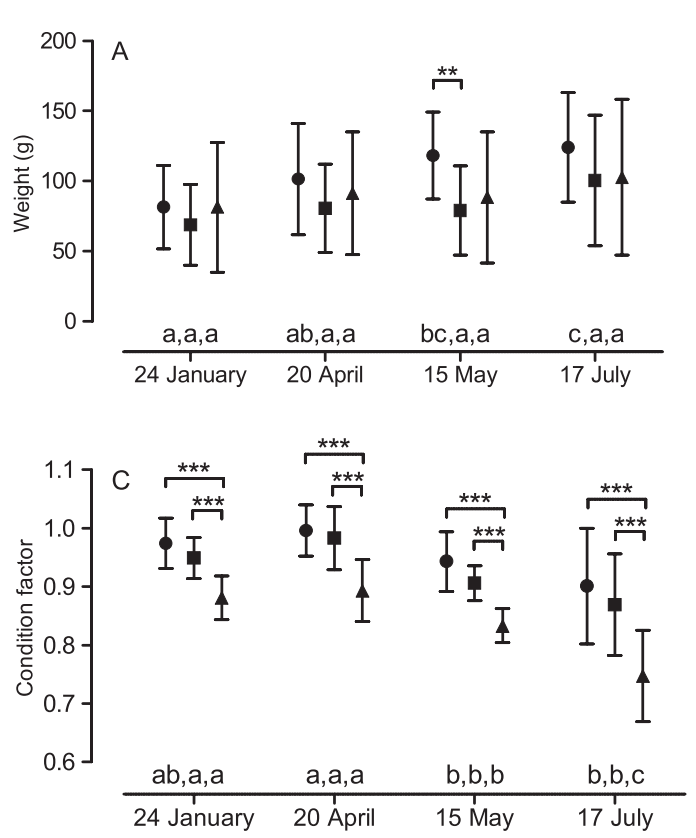

omitted from subsequent analyses and DnaJ2 was used as the sole reference gene.

\section{Statistical analyses}

The data from precocious males were removed before statistical analyses. Effects of stock and sampling time on the different physiological parameters were tested using a nonparametric Kruskal-Wallis test because all the data were not normally distributed even after log-transformation. Significant differences were further analysed using a Dwass-Steel-Critchlow-Fligner post hoc test. A Mann-Whitney test were used to examine differences in parameters between the fish held in freshwater and exposed to seawater. Differences in Na,K-ATPase isoforms between the stocks at each sampling date were analyzed by the Friedman test.

\section{Results}

\section{Fish size and condition}

Fish belonging to different stocks were similar in size, the only statistically significant differ-

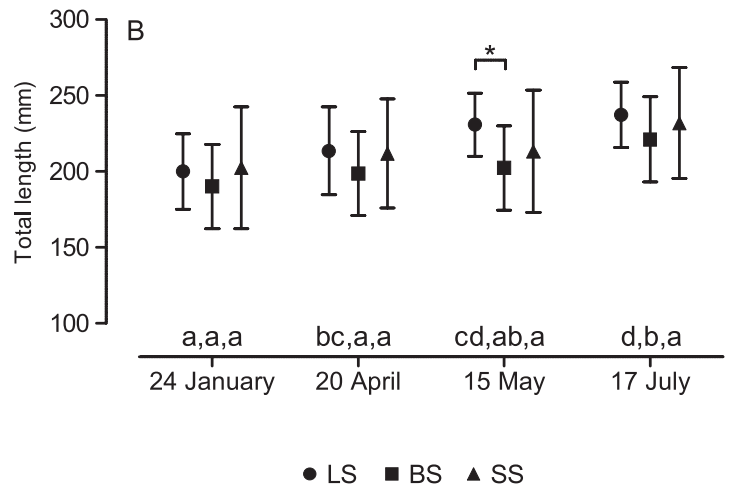

Fig. 2. (A) Body mass, (B) total length, and (C) condition factor of the fish used in the experiments. The results are means \pm SD of 18 fish for all salmon stocks. Asterisks indicate statistically significant differences $\left({ }^{*} p<0.05,{ }^{* *} p<0.01\right)$ between the stocks. Dissimilar letters show statistically significant differences $(p<$ 0.05 ) between different sampling dates. LS = landlocked stock, BS = brackish-water stock, and SS = seawater stock.

ence was the larger size of LS in comparison with BS in May $(p<0.05)$ (Fig. 2). SS had lower condition factor than LS or BS. Condition factor declined in all stocks from April to July (Fig. 2).

\section{Osmolality and ion concentrations of blood plasma}

Smoltification involves a profound change in ion regulation and therefore plasma ion concentrations and osmolality were measured during the development of the fish (Fig. 3). In all salmon stocks, there was about $6 \%$ decline in plasma osmolality from April to July. This was associated with simultaneous decline $(6 \%-33 \%)$ in plasma $\mathrm{Na}^{+}, \mathrm{Cl}^{-}$and $\mathrm{Mg}^{2+}$ concentrations. Concentration of plasma $\mathrm{K}^{+}$was the lowest in January, and slightly increased during smoltification in all salmon stocks. In contrast to $\mathrm{Na}^{+}, \mathrm{K}^{+}$and $\mathrm{Cl}^{-}$ions, concentration of $\mathrm{Mg}^{2+}$ in the postsmolt fish (in July) recovered to the level determined in April. There were only minor differences in ion concentrations between stocks. LS tended to have slightly higher $\mathrm{Na}^{+}$and $\mathrm{Cl}^{-}$concentrations than BS and SS from January until May, whereas in July no statistically significant differences among the stocks were found. SS had always 

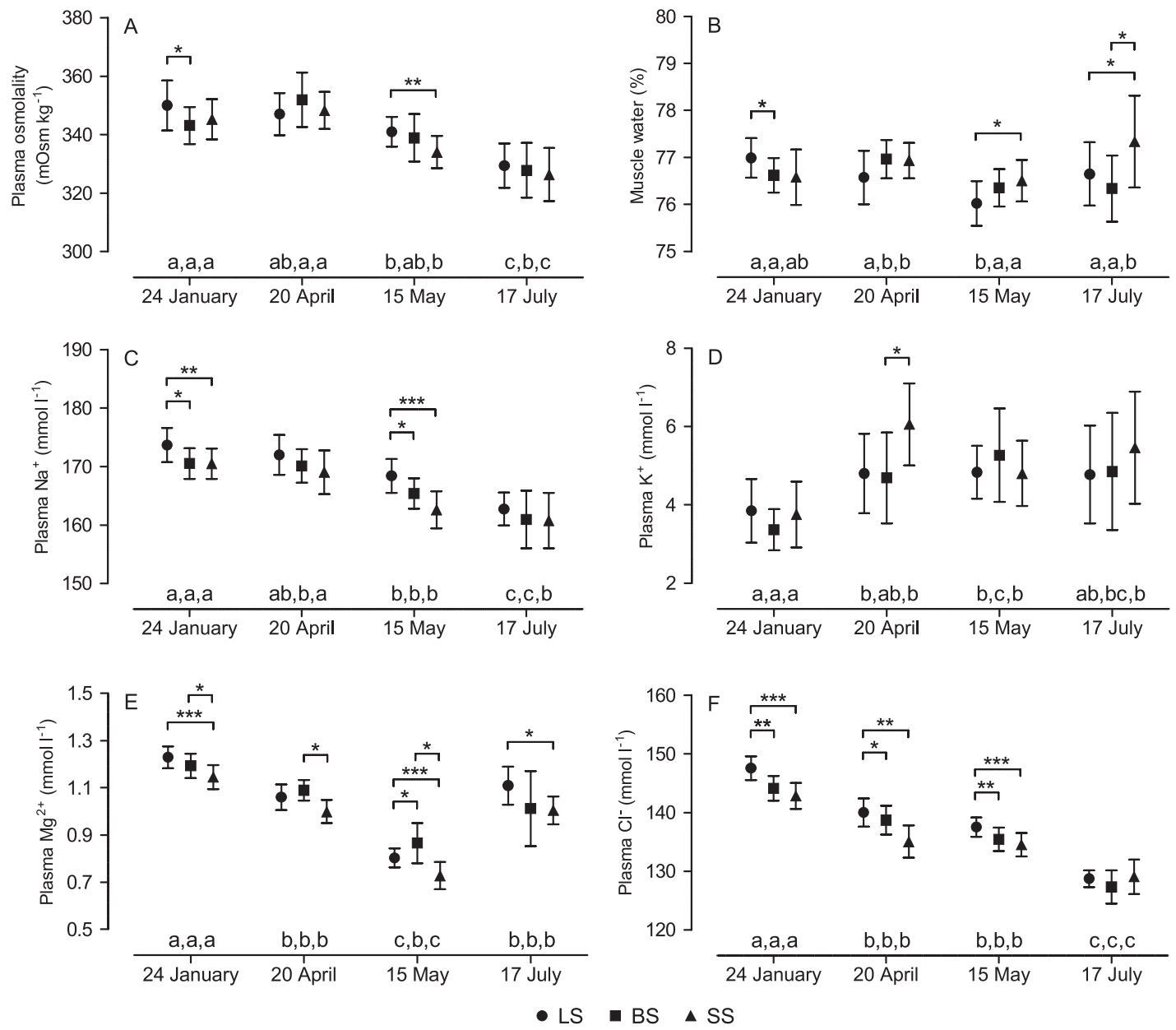

Fig. 3. (A) Osmolarity of blood plasma, (B) muscle water content, and concentrations of (C) $\mathrm{Na}^{+}$, (D) $\mathrm{K}^{+},(\mathbf{E}) \mathrm{Mg}^{2+}$ and $(\mathbf{F}) \mathrm{Cl}^{-}$ions in the blood plasma of smolting Atlantic salmon. The results are means \pm SD of 18 fish for all salmon stocks. Asterisks indicate statistically significant differences $\left({ }^{*} p<0.05,{ }^{* *} p<0.01,{ }^{* *} p<0.001\right)$ between the stocks. Dissimilar letters show statistically significant differences $(p<0.05)$ between different sampling dates. LS = landlocked stock, BS = brackish-water stock, and SS = seawater stock.

the lowest $\mathrm{Mg}^{2+}$ concentrations, and in May all stocks differed from each other. In spite of some stock-specific differences in plasma ion concentrations, their temporal development was similar in all three salmons stocks.

\section{Muscle water}

There were little temporal or stock-specific changes in muscle water content, all the values varying between $76.0 \% \pm 0.88 \%$ and $77.3 \% \pm$ $1.1 \%$ (Fig. 3b). Generally, the lowest water contents were measured in May. In January, LS had significantly higher muscle water content than $\mathrm{BS}$, whereas in May and July the highest water contents were found in SS.

\section{$\mathrm{Na}, \mathrm{K}-\mathrm{ATPase}$ activities and $\left[{ }^{3} \mathrm{H}\right]$ ouabain binding}

In all stocks, activity of gill $\mathrm{Na}, \mathrm{K}$-ATPase was low in January, increased to a peak value in May and thereafter sank to its minimum in July (Fig. 4a). Na,K-ATPase activity of the kidney was almost an order of magnitude higher than that of the gill. Activity of the kidney enzyme 

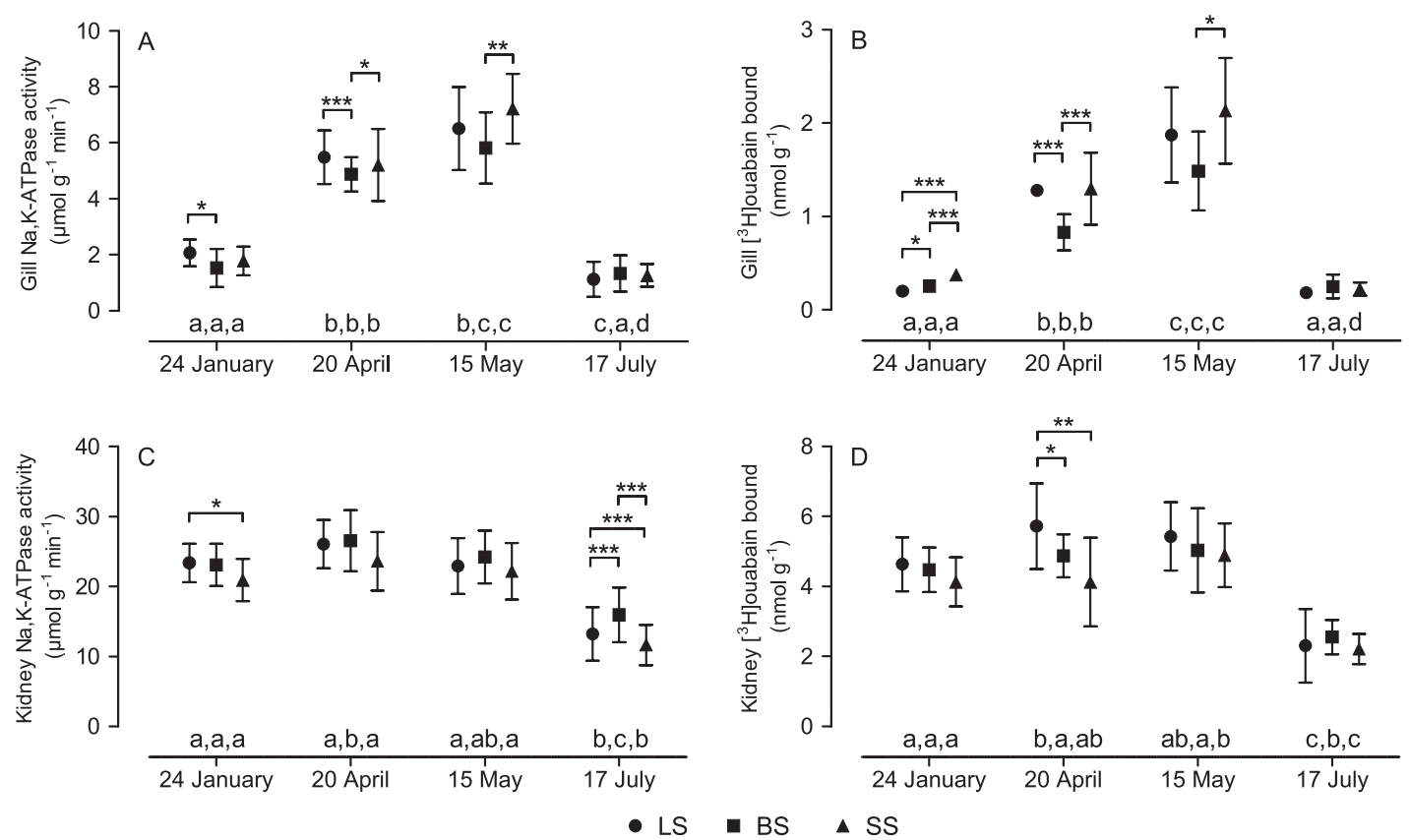

Fig. 4. (A, C) Na,K-ATPase acitivities and (B, D) $\left[{ }^{3} \mathrm{H}\right]$ ouabain binding in gill and kidney of the smolting Atlantic salmon. The results are means \pm SD of 18 fish for all salmon stocks. Asterisks indicate statistically significant differences $\left({ }^{*} p<0.05,{ }^{* *} p<0.01,{ }^{* *} p<0.001\right)$ between the stocks. Dissimilar letters show statistically significant differences $(p<0.05)$ between different sampling dates. LS = landlocked stock, BS = brackish-water stock, and SS = seawater stock.

remained high during smoltification, but strongly declined in July (Fig. 4c). The differences in $\mathrm{Na}, \mathrm{K}$-ATPase among stocks were maximally $12 \%$ and $6 \%$ for the gill and kidney enzyme, respectively. Generally, slightly lower activities of gill ATPase were found in the BS stock, whereas LS and SS did not differ from each other at any time. Small stock-specific differences in kidney $\mathrm{Na}, \mathrm{K}$-ATPase activity were detected in January and July.

Changes in the number of gill and kidney sodium pumps were analyzed using $\left[{ }^{3} \mathrm{H}\right]$ ouabain binding. Seasonal changes in both gill and kidney sodium pumps were closely correlated with those in the Na,K-ATPase activity. In all stocks, the number of gill sodium pumps was low in January and increased to the maximum in May. In July, there was a drastic drop in pump numbers to the initial level measured in January (LS and BS) or even below it (SS). The July values were only $10 \%-17 \%$ of the peak values in May. Kidney tissue contained more sodium pumps than gill tissue, and the number of kidney pumps remained fairly stable during smoltification. However, in July the number kidney pumps dropped to less than half of the preceding level. There were some differences in the total number of gill sodium pump units between the salmon stocks. In spring, the number of pumps was lowest in BS and highest in SS. In July, the stocks did not differ in their gill sodium pump numbers. In kidney pumps, the only statistically significant difference between the stocks was the higher pump number in LS in April.

\section{$\mathrm{Na}, \mathrm{K}-\mathrm{ATP}$ ase isoform transcripts of the gill}

Seasonal changes in transcript abundances of the two gill $\mathrm{Na}, \mathrm{K}$-ATPase $\alpha$-isoforms were reversed in all salmon stocks: expression of the $\alpha 1 \mathrm{a}$ isoform decreased during smoltification and was the lowest in April when expression of the $\alpha 1 \mathrm{~b}$ isoform reached its peak value (Fig. 5). In July, expression of $\alpha 1 \mathrm{~b}$ surged down below the ini- 

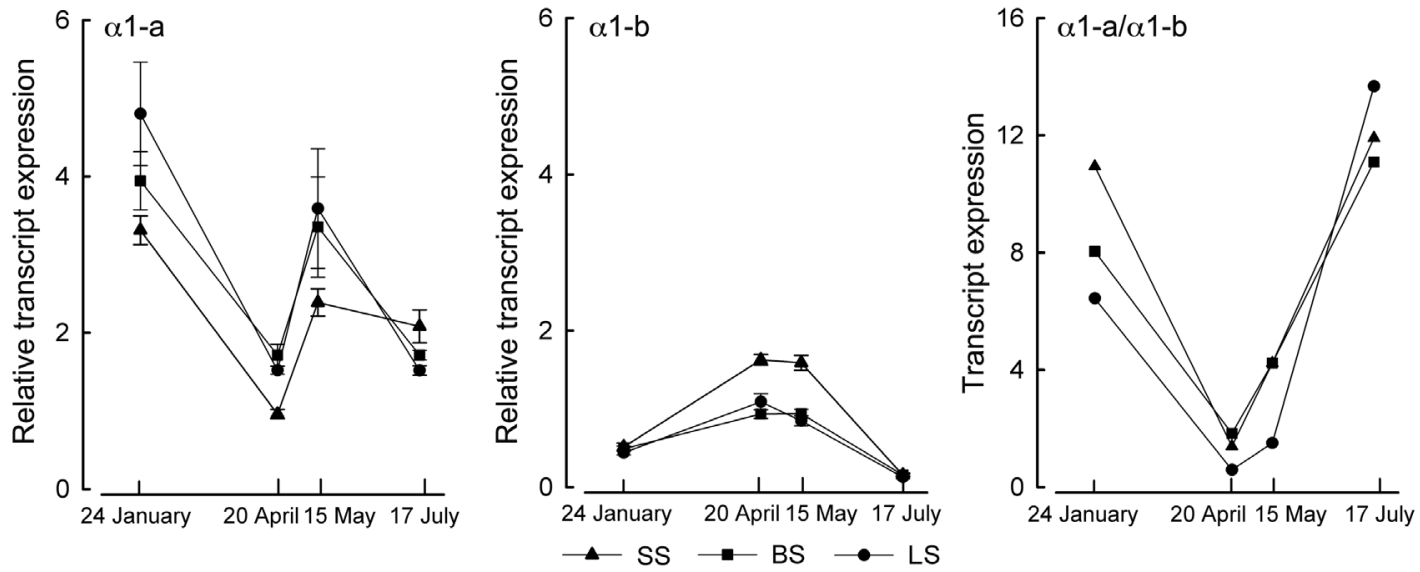

Fig. 5. Expression of the Na,K-ATPase (A) $\alpha 1 \mathrm{a}$ and (B) $\alpha 1 \mathrm{~b}$ isoform transcripts, and (C) their ratio in the gill of the smolting Atlantic salmon. The results represent 5 technical replicates of pooled samples from 4 fish for each stock and time point (total number of RNA preparations $=12$ ). LS = landlocked stock, BS = brackish-water stock, and SS = seawater stock.

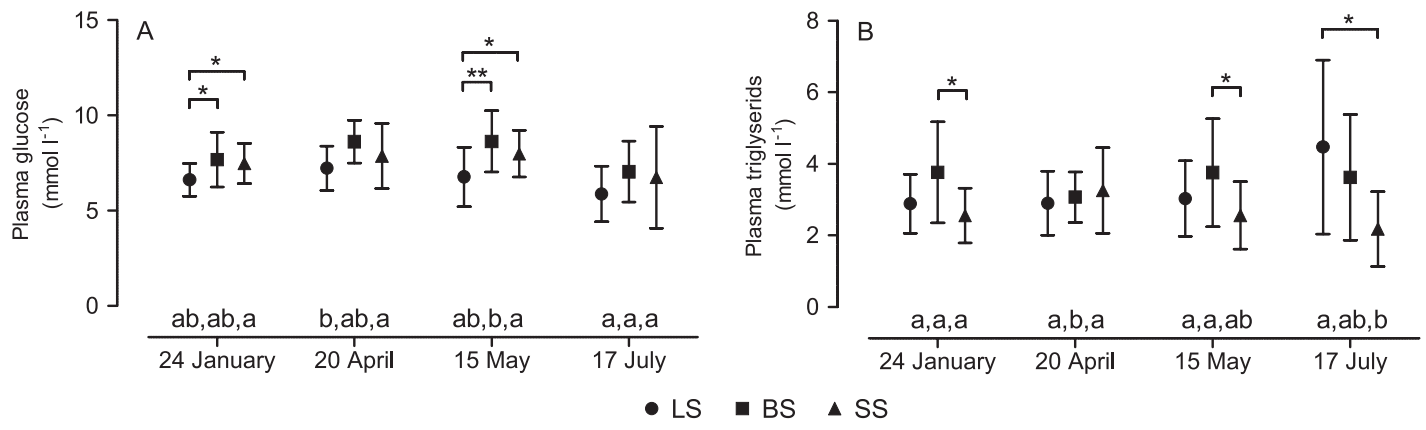

Fig. 6. Concentrations of $(\mathbf{A})$ glucose and (B) triglycerides in the blood plasma of the smolting Atlantic salmon. The results are means \pm SD of 14 to 18 fish for all salmon stocks. Asterisks indicate statistically significant differences $\left({ }^{*} p\right.$ $<0.05,{ }^{\star *} p<0.01$ ) between the stocks. LS = landlocked stock, BS = brackish-water stock, and SS = seawater stock.

tial control level measured in January, whereas the expression of $\alpha 1$ a remained low. Consequently, in July the ratio of $\alpha 1 \mathrm{a} / \alpha 1 \mathrm{~b}$ reverted back to the initial control level of the parr fish (or slightly higher). No statistically significant differences were evident in isoform abundance among the salmon stocks on different sampling dates (Friedman test: $p=0.105$ ).

\section{Seawater tolerance tests}

All salmon stocks survived the seawater tests and showed improved osmoregulatory abilities in seawater in May as compared with those in January and July (Tables 2 and 3). LS were able to fully regulate their muscle water content and osmolality and plasma $\mathrm{Cl}^{-}$and $\mathrm{K}^{+}$concentrations in seawater, while concentrations of plasma $\mathrm{Na}^{+}$ and $\mathrm{Mg}^{2+}$ were significantly higher than in freshwater fish. Similar patterns were observed in the other stocks with the exception of a significantly higher plasma osmolality in BS and SS in seawater. Compared with freshwater group, BS fish exposed to seawater had also significantly lower muscle water content.

\section{Glucose and triglycerides of the blood plasma}

Concentrations of plasma glucose and triglyc- 


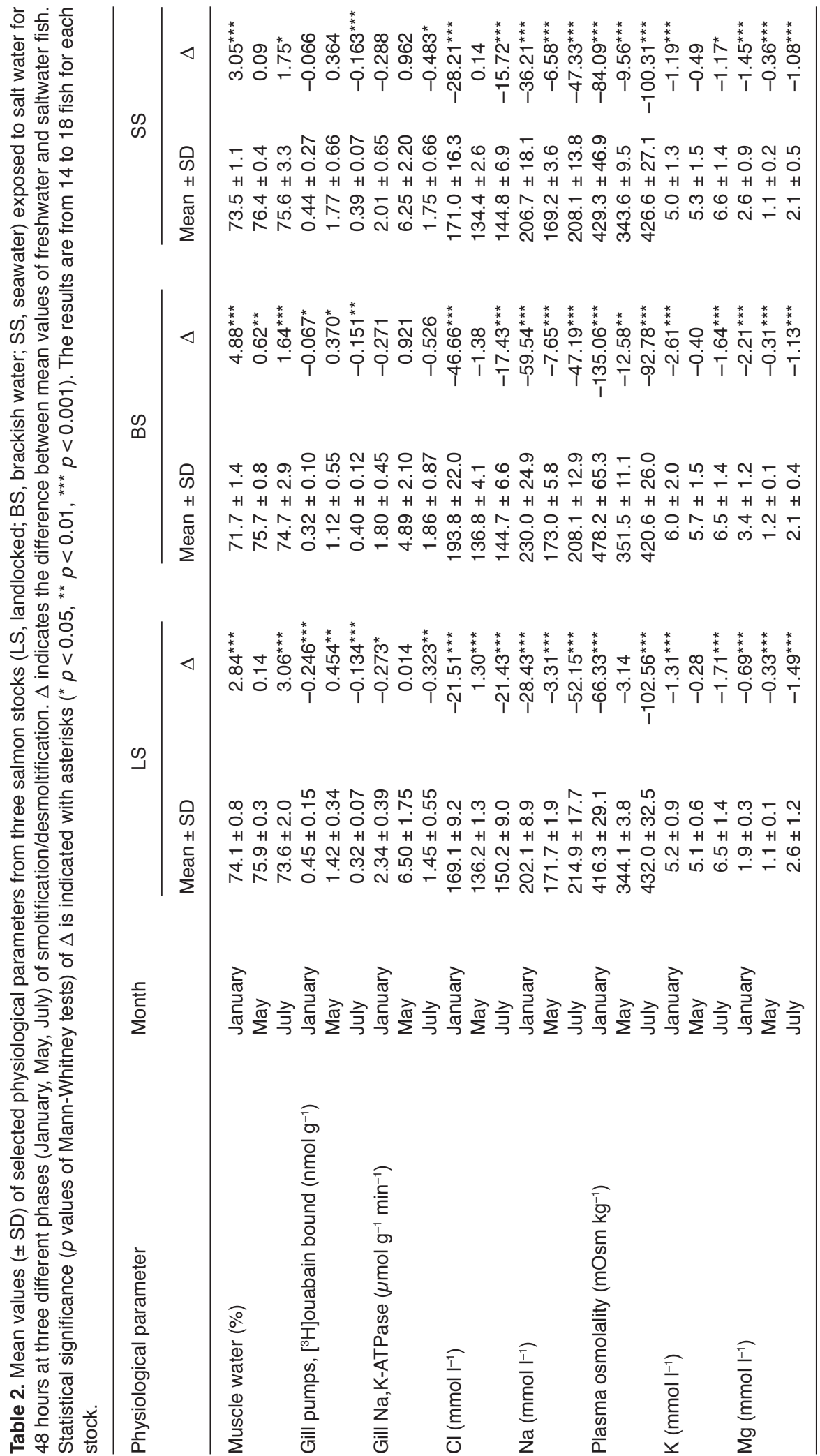


erides were 6-9 and 2-5 mmol $\mathrm{l}^{-1}$, respectively, without marked seasonal changes (Fig. 6). Concentration of plasma glucose tended to be the lowest in all stocks in July. LS had the lowest plasma glucose concentration on all sampling occasions, and in January and May differences were also statistically significant. SS had the lowest plasma triglyceride values in January, May and July.

\section{Discussion}

\section{Biology of smolting}

Smoltification in salmon is seen as preadaptation of young fish for a habitat shift from freshwater river to full strength seawater of the ocean (Folmar \& Dickhoff 1980, McCormick \& Saunders 1987). This process involves profound changes in morphology, physiology and behaviour of the fish which support successful migration of the fish from a habitat which is too barren to support fast growth to a habitat that provides plenty of food for growth and maturation. To be adaptive, the advantages of the habitat shift must exceed the energetic costs and different risks which smoltification and migration may impose to the young salmon (Hoar 1976). Inversely, if the advantages of smoltification and habitat shift have for some reason disappeared, this is expected to have resulted in weakening of smolt characteristics due to negative selection pressures.

\section{Smoltification of landlocked salmon}

The postglacial elevation of land has prevented the access of several salmon populations to the sea, creating landlocked salmon stocks which do not anymore experience the osmotic challenges of the anadromous salmon. Consistent with this, it has been noticed that many smolt characteristics of the nonanadromous Atlantic salmon populations have either markedly weakened or even totally disappeared (Barbour \& Garside 1983, Birt et al. 1991, Birt \& Green 1993, Nilsen et al. 2003, Nilsen et al. 2007, Nilsen et al. 2008). For example Birt and Green (1993) showed that the
ஸิ

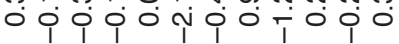

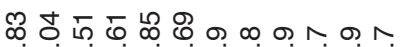

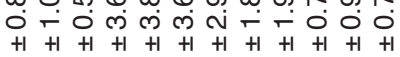

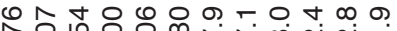
穴 ต่ เ่ ล่ ลั่

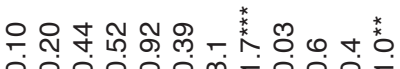
í

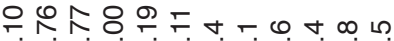
- Oо m m r $+1+1+1+1+1+1+1+1+1+1+1+1$

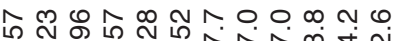
ช

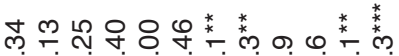
OO

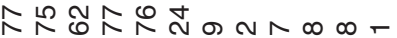

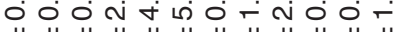

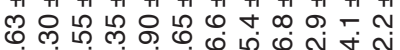
अं ले लें 
nonanadromous salmon stock of Five Mile Pond (Newfoundland, Canada) showed poor seawater tolerance, larger increases in plasma $\mathrm{Na}^{+}$and $\mathrm{Cl}^{-}$and markedly lower gill Na,K-ATPase activities than the anadromous stock upon salt water exposure. Similarly Nilsen and colleagues found strong suppressions of smolt characteristics in the Atlantic salmon stock of Byglandsfjorden (Norway) (Nilsen et al. 2003, Nilsen et al. 2007, Nilsen et al.2008). They showed, among others, higher mortality upon exposure to salt water (Nilsen et al. 2003), about 50\% lower Na,KATPase activity (Nilsen et al. 2003, Nilsen et al. 2007), little increase in transcripts of the saltwater isoform of $\mathrm{Na}, \mathrm{K}$-ATPase $\alpha \mathrm{lb}$, and significantly smaller decrease in transcripts of the freshwater isoform of Na,K-ATPase $\alpha$ la (Nilsen et al. 2007) in salmon smolts of the nonanadromous stock in comparison with the anadromous salmon.

\section{Strong smolt characteristics of the landlocked Saimaa salmon}

In contrast to those findings, no dramatic differences in smolt characteristics between the anadromous and nonanadromous Atlantic salmon stocks were found in the present study. This is consistent with the study by Seppänen et al. (2009) who found no differences in standard metabolic rate of smolting fish of the same salmon stocks. Hence, the smolt characteristics of the nonanadromous Saimaa salmon are basically similar to those of the anadromous sea-migrating Teno salmon and the brackish water Neva stock. This applies to salt water tolerance, gill Na,K-ATPase activity, number of gill Na-pumps ([$\left.{ }^{3} \mathrm{H}\right]$ ouabain binding), and gill $\mathrm{Na}, \mathrm{K}$-ATPase $\alpha$-subunits in different phases of smoltification and under salt-water exposure. For example, the peak activity of the gill $\mathrm{Na}, \mathrm{K}$ ATPase and the number of gill Na-pumps in May were practically identical (values within $12 \%$ ) in LS and SS. Also the changes in plasma osmolality and ion concentration were similar during smoltification and salt-water exposure in the anadromous and nonanadromous stocks. Collectively, the present results show that based on the analysis of conventional physiological smolt characteristics of the salmonid fish, the nonanadromous LS (Saimaa salmon) does not essentially differ from the sea-run SS (Teno salmon) in regard to strength of smoltification. Indeed, similar results have earlier been published by others. Koch (1983) and Schmitz (1995) found that hypoosmoregulatory ability and salt tolerance of the nonanadromous Gullspång salmon of Lake Vänern in Sweden were as good as those of the anadromous salmon (Salmo salar) smolts. Similarly, Chernitsky and Loenko (1983) described that succinate dehydrogenase activity of the chloride cells of Lake Onega (Russia) salmon (Salmo salar) does not essentially differ from that of the anadromous stock.

\section{Biological significance of smolting in the landlocked salmon}

Obviously, different nonanadromous populations of the Atlantic salmon are not similar in regard to the parr-smolt transformation, but show fairly large differences in strength of smoltification. Therefore the question arises: Are there any clear differences in the biology of fish between salmon populations that show weakened smoltification traits and populations that have largely retained the typical smolt characteristics of the anadromous salmon? According to Dahl (1928) and Birt and Green (1993), the salmon stocks of Byglandsfjorden and Five Mile Pond, respectively, represent dwarf populations of the Atlantic salmon whose body size is stunted in their natural habitat. These stocks have, due to geographical obstacles or other reasons, lost the crucial biological advantage of migration, the ability for fast growth. In contrast, the Saimaa and Vänern salmon in their natural habitat achieve body mass several times larger (up to $20 \mathrm{~kg}$ ) than the stunted salmon populations of Byglandsfjorden and Five Mile Pond. Although the Saimaa salmon and other smolting nonanadromous stocks have lost access to the ocean, many of these populations have retained the biological benefits of migration; the nearby lake provides better growth conditions than the natal river.

Considering that smoltification and migration cause energetic costs as well as disease and predation risks to the fish (Hoar 1976, Smail et al. 
1992, Mesa et al. 1999, Kekäläinen et al. 2008), weakening of smolt characteristics in the dwarf populations of salmon could be adaptive. Analogously, persistence of strong smoltification in the nonanadromous salmon populations migrating between freshwater habitats would be biologically meaningful, if smolting includes traits that are necessary for the habitat shift (Birt et al. 1991). Therefore, it might be expected that nonanadromous salmon had dispensed with smolting changes associated with a switch to hypoosmotic regulation, yet maintained those traits necessary for migration and pelagic life in the lake (Birt et al. 1991). The fact that seawater tolerance, high $\mathrm{Na}, \mathrm{K}$-ATPase activity and $\mathrm{Na}, \mathrm{K}$-ATPase isoform switch have been retained in the Saimaa salmon and some other nonanadromous salmon populations implies that a tight genetic linkage might exist between traits involved in hypoosmotic regulation and migration behaviour (Staurnes et al. 1992, Schmitz 1995). Alternatively, some parts of the ionoregulatory changes may play a more direct role in inducing smolt migration. Comparison of nonanadromous salmon populations which differ in growth abilities and migration behaviour might shed new light on this issue and evolution of smolt characteristics in general.

In conclusion, several studies including measurement of aerobic metabolic rate (Seppänen et al. 2009), genome-wide survey of gill gene expression (Vornanen et al. 2009, Lemmetyinen et al. 2013) and physiology of ion regulation (the present study) strongly suggest that the landlocked salmon of Lake Saimaa has retained strong smolt characteristics similar to those of the anadromous sea-run stocks. Future studies should examine how common this type of smoltification is among different landlocked populations of the Atlantic salmon and other salmon species, and to clarify its biological significance in detail.

\section{Acknowledgements}

The personnel of the Saimaa hatchery are acknowledged for good care of the fish. Funding was provided by The Academy of Finland (grants 210400, 119583 and 127192) to Matti Vornanen. Anita Kervinen is appreciated for skilful technical assistance.

\section{References}

Atkinson, A., Gatenby, A. D. \& Lowe, A. G. 1973: The determination of inorganic orthophosphate in biological systems. - Biochimica et Biophysica Acta 320: 195-204.

Barbour, S. E. \& Garside, E. T. 1983: Some physiologic distinctions between freshwater and diadromus forms of the Atlantic salmon, Salmo salar L. - Canadian Journal of Zoology 61: 1165-1170.

Berg, O. K. 1985: The formation of non-anadromous populations of Atlantic salmon, Salmo salar L., in Europe. Journal of Fish Biology 27: 805-815.

Birt, T. P. \& Green, J. M. 1993: Acclimation to seawater of dwarf nonanadromous Atlantic salmon, Salmo salar. Canadian Journal of Zoology 71: 1912-1916.

Birt, T. P., Green, J. M. \& Davidson, W. S. 1991: Contrasts in development and smolting of genetically distinct sympatric anadromous and nonanadromous Atlantic salmon, Salmo salar. - Canadian Journal of Zoology 69: 2075-2084.

Björnsson, B. T. \& Bradley, T. M. 2007: Epilogue: Past successes, present misconceptions and future milestones in salmon smoltification research. - Aquaculture 273: 384-391.

Björnsson, B. T., Stefansson, S. O. \& McCormick, S. D. 2011: Environmental endocrinology of salmon smoltification. - General and Comparative Endocrinology 170: 290-298.

Blackburn, J. \& Clarke, W. C. 1987: Revised procedure for the 24 hour seawater challenge test to measure seawater adaptability of juvenile salmonids. - Canadian Technical Report of Fisheries and Aquatic Sciences 1515: $1-35$.

Blanco, G. \& Mercer, R. W. 1998: Isozymes of the $\mathrm{Na}^{+}-\mathrm{K}^{+}-$ ATPase: heterogeneity in structure, diversity in function. - American Journal of Physiology 275: F633-F650.

Blasiole, B., Canfield, V., Degrave, A., Thisse, C., Thisse, B., Rajarao, J. \& Levenson, R. 2002: Cloning, mapping, and developmental expression of sixth zebrafish $\mathrm{Na}, \mathrm{K}$ ATPase $\alpha 1$ subunit gene (atpla1a.5). - Gene Expression Patterns 2: 243-246.

Boeuf, G., Leroux, A., Gaignon, J. L. \& Harache, Y. 1985: Gill $\left(\mathrm{Na}^{+}, \mathrm{K}^{+}\right)$-ATPase activity and smolting in Atlantic salmon (Salmo salar) in France. - Aquaculture 45: $73-81$.

Borgatti, A. R., Pagliarani, A. \& Ventrella, V. 1992: Gill $\left(\mathrm{Na}^{+}+\mathrm{K}^{+}\right)$-ATPase involvement and regulation during salmonid adaptation to salt water. - Comparative Biochemistry and Physiology 102A: 637-643.

Bystriansky, J. S., Richards, J. G., Schulte, P. M. \& Ballantyne, J. S. 2006: Reciprocal expression of gill $\mathrm{Na}^{+} /$ $\mathrm{K}^{+}$-ATPase $\alpha$-subunit isoforms $\alpha 1 \mathrm{a}$ and $\alpha 1 \mathrm{~b}$ during seawater acclimation of three salmonid fishes that vary in their salinity tolerance. - Journal of Experimental Biology 209: 1848-1858.

Canfield, V. A., Loppin, B., Thisse, B., Thisse, C., Postlethwait, J. H., Mohideen, M. A., Rajarao, S. J. \& Levenson, R. 2002: Na,K-ATPase $\alpha$ and $\beta$ subunit genes exhibit unique expression patterns during zebrafish 
embryogenesis. - Mechanisms of Development 116: $51-59$.

Chernitsky, A. G. \& Loenko, A. A. 1983: The osmoregulatory system and possible ways of differentiation in ecological forms of Atlantic salmon, Salmo salar (Salmonidae). - Journal of Ichthyology 23: 84-94.

Colina, C., Rosenthal, J. J. C., DeGiorgis, J. A., Srikumar, D., Iruku, N. \& Holmgren, M. 2007: Structural basis of $\mathrm{Na}^{+} / \mathrm{K}^{+}$-ATPase adaptation to marine environments. Nature Structural Biology 14: 427-431.

Dahl, K. 1928: The "blege” or dwarf-salmon. - Skrifter utgiven av det norske videnskapsakademi, Oslo.

Evans, D. H., Piermarini, P. M. \& Choe, K. P. 2005: The multifunctional fish gill: dominant site of gas exchange, osmoregulation, acid-base regulation, and excretion of nitrogenous waste. - Physiological Reviews 85: 97-177.

Folmar, L. C. \& Dickhoff, W. W. 1980: The parr-smolt transformation (smoltification) and seawater adaptation in salmonids. - Aquaculture 21: 1-37.

Gharbi, K., Ferguson, M. \& Danzmann, R. 2005: Characterization of Na, K-ATPase genes in Atlantic salmon (Salmo salar) and comparative genomic organization with rainbow trout (Oncorhynchus mykiss). - Molecular Genetics and Genomics 273: 474-483.

Gindler, E. M. \& Heth, D. A. 1971: Colorimteric determination with bound 'calmagite' of magnesium in human blood serum. - Clinical Chemistry 17: 662.

Hassinen, M., Paajanen, V., Haverinen, J., Eronen, H. \& Vornanen, M. 2007: Cloning and expression of cardiac Kir2.1 and Kir2.2 channels in thermally acclimated rainbow trout. - American Journal of Physiology 292: R2328-R2339.

Hoar, W. S. 1976: Smolt transformation: evolution, behavior and physiology. - Journal of the Fisheries Research Board of Canada 33: 1234-1252.

Kekäläinen, J., Niva, T. \& Huuskonen, H. 2008: Pike predation on hatchery-reared Atlantic salmon smolts in a northern Baltic river. - Ecology of Freshwater Fish 17: 100-109.

Kiiskinen, P., Hyvärinen, H. \& Piironen, J. 2002: Smolting and seasonal variation in the smolt characteristics of one- and two-year-old Saimaa landlocked salmon under fish farm conditions. - Journal of Fish Biology 60: 1015-1030.

Koch, H. J. A. E. 1983: Régulation minérale et hémoglobine chez quelques saumons (Salmo salar L.) dulçaquicoles. - Annales de la Société Royale Zoologique de Belgique 113 (suppl. 1): 259-270.

Lemmetyinen, J., Piironen, J., Kiiskinen, P., Hassinen, M. \& Vornanen, M. 2013: Comparison of gene expression in the gill of salmon (Salmo salar) smolts from anadromous and landlocked populations. - Annales Zoologici Fennici 50: 16-35.

MacCrimmon, H. R. \& Gots, B. L. 1979: World distribution of Atlantic salmon, Salmo salar. - Journal of the Fisheries Research Board of Canada 36: 422-457.

Madsen, S. S., Kiilerich, P. \& Tipsmark, C. K. 2009: Multiplicity of expression of $\mathrm{Na}^{+}, \mathrm{K}^{+}$-ATPase $\alpha$-subunit isoforms in the gill of Atlantic salmon (Salmo salar): cellular localisation and absolute quantification in response to salinity change. - Journal of Experimental Biology 212: 78-88.

McCormick, S. D. \& Saunders, R. L. 1987: Preparatory physiological adaptations for marine life of salmonids: osmoregulation, growth, and metabolism. - American Fisheries Society Symposium 1: 211-229.

McCormick, S. D., Regish, A. M. \& Christensen, A. K. 2009: Distinct freshwater and seawater isoforms of $\mathrm{Na}+\mathrm{K}+-$ ATPase in gill chloride cells of Atlantic salmon. - Journal of Experimental Biology 212: 3994-4001.

McDowall, R. M. 1988: Life history deviation and landlocking. - In: McDowall, R. M. (ed.), Diadromy in fishes: migrations between freshwater and marine environments: 171-185. Chapman \& Hall, London.

Mesa, M. G., Maule, A. G., Poe, T. P. \& Schreck, C. B. 1999: Influence of bacterial kidney disease on smoltification in salmonids: is it a case of double jeopardy? - Aquaculture 174: 25-41.

Nilsen, T. O., Ebbesson, L. O. E. \& Stefansson, S. O. 2003: Smolting in anadromous and landlocked strains of Atlantic salmon (Salmo salar). - Aquaculture 222: 71-82.

Nilsen, T. O., Ebbesson, L. O. E., Kiilerich, P., Bjornsson, B. T., Madsen, S. S., McCormick, S. D. \& Stefansson, S. O. 2008: Endocrine systems in juvenile anadromous and landlocked Atlantic salmon (Salmo salar): Seasonal development and seawater acclimation. - General and Comparative Endocrinology 155: 762-772.

Nilsen, T. O., Ebbesson, L. O. E., Madsen, S. S., McCormick, S. D., Andersson, E., Bjornsson, B. T., Prunet, P. \& Stefansson, S. O. 2007: Differential expression of gill $\mathrm{Na}^{+}, \mathrm{K}^{+}$-ATPase $\alpha$ - and $\beta$-subunits, $\mathrm{Na}^{+}, \mathrm{K}^{+}, 2 \mathrm{Cl}^{-}$cotransporter and CFTR anion channel in juvenile anadromous and landlocked Atlantic salmon Salmo salar. - Journal of Experimental Biology 210: 2885-2896.

Rajarao, S. J. R., Canfield, V. A., Mohideen, M. A. P. K., Yan, Y. L., Postlethwait, J. H., Cheng, K. C. \& Levenson, R. 2001: The repertoire of Na,K-ATPase $\alpha$ and $\beta$ subunit genes expressed in the zebrafish, Danio rerio. Genome Research 11: 1211-1220.

Richards, J. G., Semple, J. W., Bystriansky, J. S. \& Schulte, P. M. 2003: $\mathrm{Na}^{+} / \mathrm{K}^{+}$-ATPase $\alpha$-isoform switching in gills of rainbow trout (Oncorhynchus mykiss) during salinity transfer. - Journal of Experimental Biology 206: 4475-4486.

Saunders, R. L. \& Henderson, E. B. 1978: Changes in gill ATPase activity and smolt status of Atlantic salmon (Salmo salar). - Journal of the Fisheries Research Board of Canada 35: 1542-1546.

Schmitz, M. 1995: Seasonal changes in hypoosmoregulatory ability in landlocked and anadromous populations of Arctic charr, Salvelinus alpinus, and Atlantic salmon, Salmo salar. - Environmental Biology of Fishes 42: 401-412.

Seidelin, M., Madsen, S. S., Cutler, C. P. \& Cramb, G. 2001: Expression of gill vacuolar-type $\mathrm{H}^{+}$-ATPase $\beta$ subunit, and $\mathrm{Na}^{+}, \mathrm{K}^{+}$-ATPase $\alpha_{1}$ and $\beta_{1}$ subunit messenger RNAs in smolting Salmo salar. - Zoological Science 18: 315-324.

Seppänen, E., Piironen, J. \& Huuskonen, H. 2009: Standard metabolic rate, growth rate and smolting of the juveniles 
in three Atlantic salmon stocks. - Boreal Environment Research 14: 369-381.

Smail, D. A., Bruno, D. W., Dear, G., McFarlane, L. A. \& Ross, K. 1992: Infectious pancreatic necrosis (IPN) virus $\mathrm{Sp}$ serotype in farmed Atlantic salmon, Salmo salar L., posts-molts associated with mortality and clinical disease. - Journal of Fish Diseases 15: 77-83.

Staurnes, M., Lysfjord, G. \& Berg, O. K. 1992: Parr-smolt transformation of a nonanadromous population of Atlantic salmon (Salmo salar) in Norway. - Canadian Journal of Zoology 70: 1997-1199.

Sullivan, G. V., Fryer, J. N. \& Perry, S. F. 1996: Localization of mRNA for proton pump ( $\mathrm{H}^{+}$-ATPase) and $\mathrm{Cl}^{-} / \mathrm{HCO}_{3}$ exchanger in rainbow trout gill. - Canadian Journal of Zoology 74: 2095-2103.

Thorpe, J. E. 1994: An alternative view of smolting in salmonids. - Aquaculture 121: 105-113.

Tonteri, A., Titov, S., Veselov, A., Zubchenko, A., Koskinen, M. T., Lesbarrères, D., Kaluzhin, S., Bakhmet, I., Lumme, J. \& Primmer, C. R. 2005: Phylogeography of anadromous and non-anadromous Atlantic salmon (Salmo salar) from northern Europe. - Annales Zoo- logici Fennici 42: 1-22.

Trinder, P. 1969: Determination of glucose in blood using glucose oxidase with an alternative oxygen acceptor. Annals of Clinical Biochemistry 6: 24-27.

Vornanen, M. \& Paajanen, V. 2006: Seasonal changes in glycogen content and $\mathrm{Na}^{+}-\mathrm{K}^{+}$-ATPase activity in the brain of crucian carp. - American Journal of Physiology 291: R1482-R1489.

Vornanen, M., Hassinen, M., Koskinen, H. \& Krasnov, A. 2005: Steady-state effects of temperature acclimation on the transcriptome of the rainbow trout heart. - American Journal of Physiology 289: R1177-R1184.

Vornanen, M., Lemmetyinen, J., Piironen, J. \& Kiiskinen, P. 2009: Gene expression of the gill epithelium in three salmon (Salmo salar) stocks migrating to freshwater, brackish water or full-strength seawater. - Comparative Biochemistry and Physiology 154(1), S3-S3, doi:10.1016/j.cbpa.2009.05.020.

Wahleweld, A. W. 1974: Triglycerides. Determination after enzymatic hydrolysis. - In: Bergmeyer, H. U. (ed.), Methods of enzymatic analysis, vol. 4: 1831-1835. Academic Press, New York. 